\title{
Part I - Sudden Cardiac Death in Athletes Pathophysiologic Screening: A Transformative Solution to a Social Imperative
}

\author{
Timothy E. Paterick ${ }^{1 *}$, Naila Choudhary², Krishnaswamy Chandrasekaran ${ }^{3}$, A. Jamil Tajik ${ }^{5}$ and Jim Seward ${ }^{4}$ \\ ${ }^{1}$ Professor of Medicine, Director of Noninvasive Imaging, University of Florida College of Medicine, Jacksonville FL, USA \\ ${ }^{2}$ Cardiology Fellow, University of Florida College of Medicine, Jacksonville FL, USA \\ ${ }^{3}$ Professor of Medicine, Mayo College of Medicine, Rochester, MN, USA \\ ${ }^{5}$ Professor of Adult and Pediatric Cardiology, Emeritus Nasseff Professor of Cardiology Mayo Clinic, Rochester, MN, USA \\ ${ }^{4}$ Professor of Cardiology, Pediatrics and Adult Congenital Heart Disease, Aurora St. Luke's Medical Center, Milwaukee WI, USA
}

\begin{abstract}
Received: May 05, 2015; Accepted: November 09, 2015; Published: December 31, 2015
*Corresponding author: Timothy E. Paterick, Professor of Medicine, Director of Noninvasive Imaging, University of Florida College of Medicine, Jacksonville FL, USA; Email: tpaterick@gmail.com
\end{abstract}

\begin{abstract}
Sudden death in an athlete is a tragic event. There is a strong social imperative to implement effective means of predicting and preventing sudden death in competitive athletes. However, the design and implementation of a proven screening solution remains elusive $[2,3]$.To date large scale preparticipation screening has been ineffectual because it is focused on costly disease diagnosis and risk factor associations, and not on pathophysiologic effectors known to quantify a cardiovascular (CV)"risk state". The problem is that disease diagnosis does not quantify risk, [4] and statistical associations do not adequately define cause[5].Causality can be proven only by demonstrating a quantifiable cause and effect mechanism $[4,6,7]$. A preparticipation examination should be focused on quantifiable features that have been conclusively proven to measure the magnitude of risk, and illuminate a cause-and-effect relationship between the intensity of CV risk (cause) and an emergent CV disease (effect).

The barrier to changing current preparticipation screening lies in the continued acquiescence to existing opinions that are based on risk factor associations [8]. The first step to changing this approach is to break the code of silence, which sustains the status quo [9]. The medical community needs to step out of the box, applying clinical systems biology cause-and-effect prediction for the quantification and management of dynamic disease processes using echo Doppler diastolic parameters. An individual's "pre-emergent risk" state is defined as abnormal diastolic parameters before there is phenotypic expression of disease. The diastolic parameters can be used to distinguish a benign from malignant state. This distinction is an essential component of a "focused" preparticipation screening examination. A"focused" preparticipation screening exam has the capacity to reduce cost, increase quality, and effectively address the social imperative of preventing unanticipated athletic field death across the spectrum of athletic activities and age groups.
\end{abstract}

\section{Introduction}

Athletes are perceived to be the healthiest members of our society. A healthy appearing athlete may harbor an unsuspected disease process capable of triggering stress-induced sudden death $[10,11]$. An unexpected death during training or athletic competition is a particularly tragic occurrence $[12,13]$. Although infrequently encountered, addressing athletic sudden death has become a major societal imperative, [14-17] yet there is no universally accepted pre-participation screening exam in asymptomatic athletes [2]. This manuscript is a critical review of this subject.

\section{Screening}

Cardiovascular disease (CVD) is the leading cause of death in the developed countries, and many who die suddenly of CVD have no previous symptoms [18]. The definition of screening is a test offered to asymptomatic people who may, or may not, have a disease or disease precursors [19]. The test should estimate the level of "pre-emergent risk" and determine whether a diagnostic test is justified. A screening exam should not to be used for disease diagnosis, management, or a substitute for a comprehensive health assessment Table 1.

\section{Literature Review}

The incidence of sudden cardiac death in athletes has been extensively studied [20-22]. However, population based studiescontainvarying interpretations, content,conclusions, and associations [23]. Harmon et al studied sudden death in 273 athletes between 2004 and 2008. Harmon identified that accidents accounted for $51 \%$ of the sudden athletic deaths. The second most common cause of death was cardiovascular (16\%). However, this manuscript made no mention of the type of cardiac disease associated with sudden athletic field death [20]. Maron reviewed 1866 sudden deaths in young competitive athletes between 1980 and 2006. Maron identified that $56 \%$ of the deaths were cardiovascular in nature. In this population hypertrophic cardiomyopathy was attributed to $20 \%$ of the deaths and anomalous coronaries $17 \%$. Other associated diagnoses included 


\begin{tabular}{|l|l|l|l|}
\hline Table 1 Characteristics of a Good Screening Test [19]. & \multicolumn{2}{l|}{} \\
\hline Objectives & Question and Answers & $\begin{array}{l}\text { Essential } \\
\text { Characteristics }\end{array}$ & $\begin{array}{l}\text { Essential } \\
\text { Pathophysiology }\end{array}$ \\
\hline Detect a Preclinical disease & $\begin{array}{l}\text { Is Sudden Death in Healthy } \\
\text { Athletes a } \\
\text { Significant Priority? }\end{array}$ & $\begin{array}{l}\text { Widely available; } \\
\text { Echocardiographic } \\
\text { Pathophysiology }\end{array}$ & Low false positives \\
\hline $\begin{array}{l}\text { Characterize and Quantify } \\
\text { ARisk State }\end{array}$ & $\begin{array}{l}\text { Pre-emergent disease state } \\
\text { treatable? }\end{array}$ & $\begin{array}{l}\text { Safe; } \\
\text { Noninvasive }\end{array}$ & $\begin{array}{l}\text { Lnambiguous; } \\
\text { Inexpensive; } \\
\text { Reasonable Cost } \\
\text { Diseased vs. Non-Diseased Persons }\end{array}$ \\
\hline & & $\begin{array}{l}\text { Prevention: } \\
\text { Sudden Death in Athletes }\end{array}$ & $\begin{array}{l}\text { Multifeature Biomarker; } \\
\text { No single feature will adequately define risk }\end{array}$ \\
\hline & & $\begin{array}{l}\text { Pre-emergent disease } \\
\text { Detection }\end{array}$ & $\begin{array}{l}\text { Causality: } \\
\text { Feature state (cause) changes in concert with } \\
\text { the emergent disease state (effect) }\end{array}$ \\
\hline
\end{tabular}

myocarditis, atherosclerotic coronary artery disease, mitral valve prolapse, aortic stenosis, and channel opathies [21]. In an Italian study (1979-1996) comprised of 269 sudden deaths in young people there was only one patient with hypertrophic cardiomyopathy, but a $22 \%$ incidence of arrhythmogenic right ventricular cardiomyopathy [24].

\section{Autopsy Data}

The majority of the medical literature on athletic heart disease is empiric, retrospective, and is based upon non-uniform associations. Based upon available autopsy data it is usually assumed to be related to structural heart disease [25]. A small number of events remain indeterminate [16, 25].Structural abnormalities identified at autopsy have not been consistently validated by physiologic and/or microcellular data, or proven to be the true cause of death. The cause of any individual athlete's death remains an enigma. Current dependence on associations and assumptions do not allow for validated determination of true cause of death

\section{Something Overlooked}

The literature lacks evidence from randomized studies using cardiovascular screening tests based upon causality $[4,18]$. Disease should not be defined or managed by measurements and ratios in isolation [23,26,27]. The pervasive use of population based associations, absence of uniform screening methodology, and the lack of a unified solution to a social imperative deserves a critical review.

\section{Background}

The fear of unexpected sudden death in athletes has led to considerable debate regarding theforms of preparticipation screening and sub-specialty medical training in sports medicine $[16,28]$. The problem with the status quo is the fact that contemporary views of human disease are based on simple correlations and associations between clinical syndromes and pathological analysis, which have been used since the $19^{\text {th }}$ century [8].

Disease processes are complex, and rarely a consequence of an abnormality in a single effector. Instead they are a reflection of multi-feature pathobiological processes that interact to yield an emergent disease. The disease process is discernible only by appreciating the conjoined effects of multiple related components $[8,29]$. A cardiovascular system remodels in a similar manner from normal athletic activity and disease related stressors[30]. This explains why a normal athlete can have morphologic features that are virtually identical to those identified in an unrelated disease process $[29,31]$.The solution to distinguish normal from abnormal pathophysiologic profiles lies in tests designed to test causality $[4,6,32]$. Sudden death in athletes is a multi-variable puzzle. Individual variations in types of sports, intensity of training, and pre-emergent disease processes create a medical challenge which cannot be effectively quantified by the physician's own inductive reasoning or regression statistics [8]. The only logical solution to this conundrum is to individualize and quantify each athlete's personal pathophysiologic state using diastolic Doppler variables linked to causation $[4,6,8]$.

\section{Current preparticipation screening}

There is a broad range of screening recommendations dependent upon the investigator(s), sporting discipline, and level of physical exertion and competition [3]. The overriding challenge is providing a common - sense, integrated strategy for prevention, while accounting for the fact that regular exercise is an activity to be encouraged. Current screening recommendations are not founded on state-of-the-art medical knowledge, but principally on general, expert consensus and associations which cannot effectively assign causation. The approach to clinical care has evolved in conjunction with evolution of the risk factor approach to diagnosis and management of disease processes. However, most of these recommendations are not supported by high quality evidence [33]. As of this date the fundamental cause of sudden death in asymptomatic athletes remains shadowed in uncertainty. An additional challenge, among 10 to 15 million athletes of various ages, is the fact that the incidence of sudden cardiac death is very low [20-22, 31, 34-36]. As a consequence of the low incidence of disease in the athletic population the current literature suggests that all cardiac imaging modalities are inadequate to justify their use as primary screening modalities in athletes, as well as the general population [2, 37]. 
Outside the athletic community, the medical community has come to the conclusion that routine exams in asymptomatic persons does little to improve health outcomes, and is largely a misappropriation of time and money [38]. A screening electrocardiogram (ECG) or stress testing are currently not recognized as acceptable screening tools in asymptomatic people $[2,21,39,40]$. Even though screening tests in asymptomatic patients have no firm evidence of utility, these tests are commonly touted as acceptable screening tools for asymptomatic athletes primarily because of lower cost and access [21]. In addition to a lack of utility, a high percentage of positive ECGs and stress test findings will be false positives [41,42], which result in anxiety and expensive adjudication $[43,44]$. As medicine evolves into the $21^{\text {st }}$ century and the new era of cause-and-effect pathophysiology evolves these issues will be resolved.

\section{Experts}

Thinking outside the box is difficult when people are in the box $[9,45]$. Experts often reside in their domain of expertise, making it difficult for them to determine the limitations, or sources of errors in their paradigms. Experts manage each solution and direct the investigative group's focus on domain explicit strategies, rather than determining how to most effectively solve the whole problem. It's difficult for an expert to look at problems holistically - to step back and think about issues that need broader investigation and how data might be most effectively used. Architecting holistically is necessary if we are to prepare ourselves to address broad, unanswered questions [8, 27]. The synergies of cross-pollination across domains have enormous potential when seeking solutions to complex problems.

One of the greatest barriers to any change lies in the continued acceptance of unproven solutions [9]. These approaches are sustained by a culture of silence. Experts know that current limitations for diagnosis and assessment of sudden death in athletes carry an enormous cost but no consortium of experts have stepped out of their domain to change the existing unproven practice patterns.

\section{Time to Change}

Medical risk assessment is about to profoundly change and revolutionize the approach to disease prevention. In the $19^{\text {th }}$ century (Era of Pathologic Correlations) medicine focused on Oslerian clinical-pathologic correlation [46]. The Oslerian formulation for human disease links clinical presentation with pathological findings following a disease - centric model. As a result disease is defined on the basis of the principal organ system in which symptoms and signs are manifest and in which gross anatomic pathology and histopathology are correlated.

In the $20^{\text {th }}$ century (Era of Risk Factors) medicine further refined pathological markers and devices used for correlation between symptoms, findings and pathology, (biochemical measures; X-ray, ECG, Ultrasound, magnetic resonance imaging (MRI), computed tomography (CT); more recently genomics), yet the general principles based on associations remained the same disease- centric model This approach overgeneralizes pathophenotypes, which do not sufficiently take into consideration susceptibility states or preclinical disease manifestations, and cannot be used to individualize disease diagnosis and therapy [4, 6-8, 33, 47-50].

As we enter the $21^{\text {st }}$ century(New Era of Pathophysiologic Cause-and-Effect) we are beginning to recognize that conventional pathophenotypes (risk factors)are too limited to be useful $[8,33,51]$. We are about to move the health care enterprise forward to reduce the burden of disease and suffering. Disease is to be looked upon as the result of the output of a complex network of interconnected nodes linked mechanistically to yield a pathophenotype [52]. Human disease is redefined using a combination of approaches to identify systems-based pathophysiological mechanisms that render one susceptible to preclinical and overt pathophenotypes. The network model can predict disease expression (sudden death in athletes) and quantify the magnitude, or intensity of risk. The nonlinear response of physiologic features under lies the emergent properties of asymptomatic disease. Physiologic networks are not random collections, but clusters of regulatory effectors $[53,54]$. All diseases are biological networks that manifest properties, which define those features that are most responsible for a specific pathobiological process or specific disease. These tenants promise to redefine our approach to disease and the field of preventive medicine. We can address sudden death in athletes as small networks of highly related combinatorial data to identify systems-based pathophysiologic mechanisms that render an athlete susceptible to preclinical and overt pathophysiologic risk. This change in medicine is made possible by the simplicity of network medicine $[47,49]$ and computer assisted intelligence $[55,56]$.

\section{Essentials of a Pathophysiologic Solution} [57].

"Simplicity is the ultimate sophistication" Leonardo da Vinci

"The likelihood that one event is the cause of another guides much of what we understand about the world and how we act in it." Judea Pearl [4]

\section{Definitions}

Pathology: Is the medical discipline that describes conditions observed during a disease state, and physiology is the biological discipline that describes processes and mechanisms operating within an emerging disease state without phenotypic expression. Combinatorial pathophysiology documents physiological processes (cause), which define the status of an evolving pathological condition $($ effect).

Essentialism [58]: An "essential" screening is an exam focused on those things that are absolutely necessary and indispensable, precluding things that are extra, or needless [58]. The low incidence of sudden cardiac death and the cost of screening athletes shape current policy decisions. To improve the policy the valued-added essential screening exam must identify those at risk at a low cost [35]. Data without sufficient discrimination, reproducibility, or validation are deemed unnecessary and dispensable. Routine physical exam, ECG, stress 
test, blood tests, complete or limited echo cardiography, CT, and MRI exams do not meet the definition of essential because they are costly and attempt to define disease rather than risk [42]. In order to markedly increase the power of discrimination (normal vs. abnormal) and substantially lower the constraints of access and cost, each feature of the screening exam must be individually scrutinized for its essential role in determining risk. An exam focused on simple essentials requires more sophistication than either a comprehensive or limited examination [59]. This does not mean that non-essentials are void of empirical content: the structural components of a disease may become relevant post the screening when viewed in conjunction with the pathophysiologic state $[4,34,35]$.

\section{Objective}

The first objective in screening should be to design a test to obtain a scrutinized set of essential data, which reflect the individual's pathophysiologic state that has the potential to deteriorate during stress [8, 60-63]. Screening designed around essentials does not compromise efficiency, completeness, or accuracy of the exam [29]. Second, the screening exam is not comprehensive, but focused on obtaining and prioritizing the most essential objectives. The acquisition of small numbers of essential data will reduce cost [47] and computer assisted data interpretation will increase exam quality and user intelligence $[55,56]$. Third, the screening exam should embrace holistic reasoning and avoid domain specific thinking.

\section{Look Alike Data}

Many compensatory morphophysiologic features look alike ("gray area") $[30,34,64]$ and are not distinctive enough to be considered unique attribute essential for a screening examination. The differences between normal and abnormal remodeling lie in the diastolic Doppler assessment and not in individual image features $[4,6,8,47,65]$. Precepts of pathophysiologic assessment include those listed in Table 2.

\section{Screening}

To date screening markers have marginal clinical benefit in determining risk [66]. Most markers are correlated with traditional risk factors and therefore do not have high independent odds ratios (relative risk). A screening test should not be considered a diagnostic test, but a triage and reclassification test $[66,67]$. Triage is a test used before an existing diagnostic test is performed, and only patients with a particular result on the triage test continue down the diagnostic pathway. A triage-screening test does not aim to improve the accuracy of the diagnostic test. It reduces the need for additional testing that may be expensive and invasive [66].

Table 2:

- Single datumwill not adequately define complex disease state;

- Population based datado not adequately define risk:

- Pre-emergent pathophysiologic datacanquantify risk;

- Individualized risk is essential:risk factorassociations do not suffice;

- Causality: Multi-feature networks are used todefine cause and effect.

\section{Guidelines}

Consensus based guidelines focus on risk factor associations that do not address cause-and-effect and do not meet the essential criteria for determination of individualized risk and causality $[6,31,68]$. Most testing modalities entrenched in consensus guidelines [68] are not capable of identifying nearterm risk(occurring within 1 year of assessment), but classify risk over many years (10 years for the Framingham Risk Score) $[69,70]$. Most clinical tests are currently known to be of little or no benefit in asymptomatic persons [26] and include: physical exam [42], resting and stress ECG [2, 37, 39, 40, 42, 43], complete, limited and/or screening echo cardiographic exam [2, 18, 26, 71], various imaging modalities such as MRI [37], CT calcium score [37], and serum biomarkers [72-74], lipid profile [75] and genomic testing [75-77].

These tests are commonly embedded in consensus guidelines [68].The imperfect specificity of ECG screening and high incidence of false positive findings [41] actually has the potential for harm through further low yield investigations, psychological stress, and unnecessary disqualifications [37]. The American College of Preventive Medicine does not recommend the ECG, exercise treadmill testing, electron-beam CT, ankle-brachial index, carotid intima thickness, or contemporary risk factors including high-sensitivity C-reactive protein in asymptomatic patients [78].The current potential for imperfect decision-making has led to a continuous debate about a suitable preparticipation athletic screening exam. Because of the enormity of the athletic population and the low incidence of sudden death the challenge is analogous to finding a needle in the haystack [20-23]. In order to definitively address this challenge we must focus on identifying and quantifying imminent risk based on validated causality; not population based associations, or long-term risk prediction.

\section{Echo/Doppler Screening Test}

Echocardiography has not been considered seriously as a primary cardiac imaging strategy, or testing modality for large-scale universal preparticipation exam because of cost, inaccessibility, and inter-observer variability [2, 37]. This decision is justified if the echo cardiographic examination is used as an expensive general diagnostic test. A good screening test is not a diagnostic test, [19] but a focused test. Echo attributes for screening are listed in Table 3.

Exams based on $20^{\text {th }}$ century risk factor assessment are fundamentally incomplete $[37,68]$ and not focused on the essential objective of determining imminent risk of sudden death [70].The art of medicine is based on a vast knowledge base, which can and should be condensed into an exam focused on causality and magnitude of pre-emergent risk $[6,8]$. It is predicted that in an asymptomatic athletic population there is a small number of persons who have a demonstrable pre-emergent risk profile, which can be managed with prudent observation, medical management, and reduced exposure to the demands of a field activity.

For the general adult population the American Heart Association guidelines for adults [37, 93] recommend risk 
Table 3: Echocardiographic Screening.

- Focused Screening: Triage and classification of CV risk [66, 67]

- High quality pathophysiologic exam[29, 79,80$]$

- Low cost focused exam[29, 65, 81-83]

- System Biology Screening[8, 47]

- Accessibility: AHA "the single most useful diagnostic test in the evaluation of patients with heart failure...." [84]

- Most peer reviewed literature (TABLE)

- Essentialism: focused echocardiogram[58]

- Anatomy correlated with function[85]

- Quantification of risk: system biology[8, 47]

- Mature multi-feature biomarker[86, 87]

- Causality (cause and effect test) $[4,6]$

- Network remodeling[29, 54, 88-91]

- Computer-assisted, centralized interpretation[56, 82]

- Remote access to expertise[92] assessment beginning at age 40 years and repeat every 5 years or sooner if there is any emerging risk concern. However, in older competitive athletes ( $>35$ years old) recurring assessment may be more important [31]. For young athletes recommendations include CV screening every 2 years with an abbreviated examination in intervening years [17]. Overall the detection of pre-emergent $\mathrm{CV}$ disease has become a polarized public health debate, triggering a large and growing body of literature, including clinical studies, editorials, opinion pieces, proclamations, and reviews on both sides of the question [2]. Most literature is based on population based studies, expert consensus, and risk factor correlations. Although echocardiography is the most robust noninvasive cardiovascular exam and multi-feature biomarker, it is perfunctorily excluded or considered second-tier, because of "inaccessibility, cost, and inter-observer variability"[2]. However, echocardiography is recognized as "the single most useful diagnostic test in the evaluation of patients with heart failure...." [84]. This designation of "most useful test" would also apply to more than $90 \%$ of all remaining conditions associated

Table 4: Disease Types andEcho/Doppler Pathophysiology.

Echo Pathophysiology

\begin{tabular}{|c|c|c|c|c|}
\hline $\begin{array}{l}\text { Disease and Sudden Death in } \\
\text { Athletes [35] }\end{array}$ & $\begin{array}{l}\text { Incidence } \\
\%\end{array}$ & Echocardiograph & hophysiology & \\
\hline Cardiomyopathy (CM) & & $\begin{array}{l}\text { Abnormal } \\
\text { Pathophysiology }\end{array}$ & $\begin{array}{l}\text { Normal } \\
\text { Athletic } \\
\text { Physiology }\end{array}$ & $\begin{array}{l}\text { Normal vs. Abnormal } \\
\text { Pathophysiology }\end{array}$ \\
\hline Hypertrophic CM & 26.4 & {$[88,94-98]$} & \multirow{10}{*}[88,98-106]{} & \multirow{10}{*}{$\begin{array}{l}\text { Essential: Myocyte relaxation (e') is an important test } \\
\text { to distinguish normal vs. abnormal pathophysiology. } \\
\text { Tissue Doppler is available on nearly every ultrasound } \\
\text { device. Obtainable in nearly } 100 \% \text { of young athletes. }\end{array}$} \\
\hline Hypertensive CM & 7.5 & {$[107,108]$} & & \\
\hline Ischemic CM & & [109] & & \\
\hline Restrictive CM & & [110] & & \\
\hline Arrhythmogenic RV CM & 5 & [111] & & \\
\hline Myocarditis & 2.8 & [112] & & \\
\hline Dilated CM & 2.3 & {$[96,109]$} & & \\
\hline Sarcoid Heart Disease & 0.8 & [110] & & \\
\hline Other & 0.8 & Echo & & \\
\hline Substance Abuse CM & 1.0 & {$[113,114]$} & & \\
\hline \multicolumn{5}{|l|}{ Hypertension, LVH } \\
\hline Hypertensive Heart Dis & \multirow[b]{2}{*}{7.5} & {$[107,115,116]$} & & \multirow[t]{2}{*}{ Essential: See CM physiologic Doppler assessment } \\
\hline Unexplained LVH & & [88] & & \\
\hline Coarctation & --- & {$[117,118]$} & & Essential: Abdominal aorta PW-Doppler [117] \\
\hline \multicolumn{4}{|l|}{ Congenital Heart Disease } & \multirow{8}{*}{$\begin{array}{l}\text { Essential: Function: Slow scan of short axis and long } \\
\text { axis of the aortic sinuses and aortic valve. } \\
\text { Essential: Anatomy: Confirm visualization of the } \\
\text { proximal coronary arteries; aortic valve leaflets. } \\
\text { Enlarged aortic root --- measure anterior posterior } \\
\text { aorta dimensions at multiple levels. }\end{array}$} \\
\hline Anomalous Coronary & 14 & {$[98,119-122]$} & $\begin{array}{l}{[21,29,81} \\
123]\end{array}$ & \\
\hline & & & & \\
\hline Aortic Aneurysm & & & [124] & \\
\hline Marfan Syndrome & 3.1 & [125-127] & & \\
\hline Bicuspid Aortic Valve (aortopathy) & --- & [128-130] & & \\
\hline Cystic Medial Necrosis & --- & [126] & & \\
\hline Tunneled Coronary Artery & 2.8 & [122] & & \\
\hline Complex Congenital & --- & [131] & [131] & Cardiac Crux [131] \\
\hline Coarctation(hypertension) & --- & {$[117,118]$} & & $\begin{array}{l}\text { Essential: Pulse wave Doppler of abdominal aorta for } \\
\text { presence and severity [117] }\end{array}$ \\
\hline
\end{tabular}




\begin{tabular}{|c|c|c|c|c|}
\hline Pulmonary Hypertension & & [132-134] & & \\
\hline Athletes $\geq 35$ yrs. old & & {$[37,135,136]$} & & \\
\hline $\begin{array}{l}\text { Atherosclerotic Coronary Artery } \\
\text { Disease (CAD) }\end{array}$ & & [137-141] & & \\
\hline Risk of Sudden Death & 2.6 & $\begin{array}{l}{[135,138]} \\
\text { CT Calcium Score } \\
{[142]}\end{array}$ & & $\begin{array}{l}\text { Essential: Risk of CAD: Cardiac function is best } \\
\text { predictor imminent risk } \\
\text { Presence of CAD: calcium score, other imaging } \\
\text { technologies detect CAD but does not predict imminent } \\
\text { risk }\end{array}$ \\
\hline Valve Disease & & & [143-145] & \\
\hline Aortic valve stenosis & 2.6 & {$[143,146]$} & & \multirow{2}{*}{$\begin{array}{l}\text { Essential: Echo/Doppler function depicts anatomic } \\
\text { presence and pathophysiologic burden, can alert need } \\
\text { for a more comprehensive exam }\end{array}$} \\
\hline Myxomatous Mitral Valve & 2.3 & [147] & & \\
\hline Complex Congenital Heart Dis. & & {$[131]$} & & \\
\hline Marfan (Aneurysm Rupture) & 3.1 & [125] & & \\
\hline Tunneled Coronary Artery & 2.8 & Not Applicable & & Angiography \\
\hline Cyanotic CHD & - & [131] & & \\
\hline Eisenmenger Syndrome & - & [132] & & \\
\hline \multicolumn{5}{|l|}{ Trauma } \\
\hline Commotio Cordis & 19.9 & [148] & & \\
\hline Heat stroke & 1.6 & [149] & & \\
\hline other & 0.8 & Not Applicable & & \\
\hline \multicolumn{5}{|l|}{ Other } \\
\hline Long QT (channelopathies) & $\begin{array}{l}0.8 \\
\text { Rare }\end{array}$ & $\begin{array}{l}\text { History }[150] 50 \% \text {, } \\
\text { Echo }[151] 20 \%, \\
\text { ECG }[41,150,152]\end{array}$ & & Electrophysiology [153] \\
\hline Ruptured Cerebral Artery & 0.8 & $\begin{array}{l}\text { Not } \\
\text { Applicable }\end{array}$ & & \\
\hline
\end{tabular}

with sudden death in athletes Table4. Echo/Doppler is a readily accessible, reproducible pathophysiologic test, [53] and universal biomarker [86, 87], which complements its role as a first order CV anatomic and hemodynamic tool. The cardiovascular community has consistently acknowledged that echocardiography has the validated potential to be the best all round screening test if the three fundamental impediments of "access, cost, and interobserver variability [2]" were definitively resolved. Part Three of this manuscript will discuss the essential features needed in screening to determine imminent risk and how to implement screening that is accessible, valid, and low cost.

\section{References}

1. Harris K. Collected Quotes from Albert Einstein. [updated 1995; cited 2014 Nov 1]; Available from: http://rescomp.stanford. edu/ cheshire/EinsteinQuotes.html

2. Maron BJ, Friedman RA, Kligfield P, Levine BD, Viskin S, Chaitman BR, et al. Assessment of the 12-lead electrocardiogram as a screening test for detection of cardiovascular disease in healthy general populations of young people (12-25 years of age): a scientific statement from the American Heart Association and the American College of Cardiology. J Am Coll Cardiol. 2014;64(14):1479-1514.
3. Corrado D, Basso C, Schiavon M, Pelliccia A, Thiene G. Pre-participation screening of young competitive athletes for prevention of sudden cardiac death. J Am Coll Cardiol. 2008;52(24):1981-1989.

4. Pearl J. Causal inference in statistics: An overview. Statistics Surveys. 2009;396-146.

5. Dallal GE. The Little Handbook of Statistical Practice. [updated 2007 Aug 8; cited 2014 Oct 8]; Available from: http://www.jerrydallal. com/LHSP/LHSP.htm

6. Lucas RM and McMichael AJ. Association or causation: evaluating links between "environment and disease". Bulletin of the World Health Organization. 2005;83(10):792-795.

7. Selhon J. Models of Causation and Tools for Causal Inference. UC Berkeley [updated; cited]; Available from: http://sekhon.berkeley. edu/papers/causality.pdf.

8. Loscalzo J, Barabasi AL. Systems biology and the future of medicine. Wiley Interdiscip Rev Syst Biol Med. 2011;3(6):619-627.

9. Grenny J, Patterson K, Maxfield D, McMillan R, Switzler AI, et al. The New Science of Leading Change. Columbus: McGraw Hill Education; 2013.

10. Maron BJ, Shirani J, Poliac LC, Mathenge R, Roberts WC, Mueller FO. 
Sudden death in young competitive athletes. Clinical, demographic and pathological profiles. JAMA. 1996;276(3):199-204.

11. Corrado D, Basso C, Rizzoli G, Schiavon M, Thiene G. Does sports activity enhance the risk of sudden death in adolescents and young adults? J Am Coll Cardiol. 2003;42(11):1959-1963.

12. Maron BJ. Sudden Death in Young Athletes -- Lessons from the Hank Gathers Affair. N Engl J Med. 1993;329(1): 55-57.

13. Maron BJ. Sudden death in young athletes. N Engl J Med. 2003;349(11):1064-1075.

14. Maron BJ. Cardiovascular risks to young person's on the athletic field Ann Intern Med. 1998;129(5):379-386.

15. Maron BJ. Distinguishing hypertrophic cardiomyopathy from athlete's heart: a clinical problem of increasing magnitude and significance. Heart. 2005;91(11):1380-1382.

16. Corrado D, Pelliccia A, Bjornstad HH, Vanhees L, Biffi A, Borjesson M, et al. Cardiovascular pre-participation screening of young competitive athletes for prevention of sudden death: proposal for a common European protocol. Consensus Statement of the Study Group of Sport Cardiology of the Working Group of Cardiac Rehabilitation and Exercise Physiology and the Working Group of Myocardial and Pericardial Diseases of the European Society of Cardiology. Eur Heart J. 2005;26(5):516-524.

17. Maron BJ, Thompson PD, Puffer JC, McGrew CA, Strong WB, Douglas PS, et al. Cardiovascular preparticipation screening of competitive athletes. A statement for health professionals from the Sudden Death Committee (clinical cardiology) and Congenital Cardiac Defects Committee (cardiovascular disease in the young), American Heart Association. Circulation. 1996;94(4):850-856.

18. Michos ED, Abraham TP. Echoing the appropriate use criteria: the role of echocardiography for cardiovascular risk assessment of the asymptomatic individual. JAMA Intern Med. 2013;173(17):15981599.

19. Lewis GH, Sheringham J, Kalim K, Crayford T. Mastering Public Health: A Guide to Examinations and Revalidation. New York: Oxford University Press;2008.

20. Harmon KG, Asif IM, Klossner D, Drezner JA. Incidence of sudden cardiac death in National Collegiate Athletic Association athletes. Circulation. 2011;123(15):1594-1600.

21. Maron BJ, Haas TS, Doerer JJ, Thompson PD, Hodges JS. Comparison of U.S. and Italian experiences with sudden cardiac deaths in young competitive athletes and implications for preparticipation screening strategies. Am J Cardiol. 2009;104(2):276-280.

22. Halabchi F, Seif-Barghi T, Mazaheri R. Sudden cardiac death in young athletes; a literature review and special considerations in Asia. Asian. 2011;2(1):1-15.

23. Sharma S, Merghani A, Gati S. Cardiac screening of young athletes prior to participation in sports: difficulties in detecting the fatally flawed among the fabulously fit. JAMA Intern Med. 2015;175(1):125-127.

24. Corrado D, Basso C, Schiavon M, Thiene G. Screening for hypertrophic cardiomyopathy in young athletes. N J Med. 1998;339(6):364-369.

25. Maron BJ, Haas TS, Murphy CJ, Ahluwalia A, Rutten-Ramos S. Incidence and causes of sudden death in U.S. college athletes. J Am Coll Cardiol. 2014;63(16):1636-1643.

26. Lindekleiv H, Lochen ML, Mathiesen EB, Njolstad I, Wilsgaard T, Schirmer H. Echocardiographic screening of the general population and long-term survival: a randomized clinical study. JAMA Intern Med.

\section{3;173(17): 1592-1598}

27. Paterick TE, Tajik AJ. Left ventricular noncompaction cardiomyopathy: lessons from the past to explain a diagnostic conundrum. J Am Soc Echocardiogr. 2014;27(10):1128-1130.

28. Mahmood S, Lim L, Akram Y, Alford-Morales S, Sherin K. Screening for sudden cardiac death before participation in high school and collegiate sports: American College of Preventive Medicine position statement on preventive practice. Am J Prev Med. 2013;45(1):130-133.

29. Weiner RB, Wang F, Hutter AM Jr, Wood MJ, Berkstresser B, McClanahan C, et al. The feasibility, diagnostic yield, and learning curve of portable echocardiography for out-of-hospital cardiovascular disease screening. J Am Soc Echocardiogr. 2012;25(5):568-575.

30. Baggish AL, Wood MJ. Athlete's heart and cardiovascular care of the athlete: scientific and clinical update. Circulation. 2011; 123(23): 2723-2735.

31. Maron BJ, Thompson PD, Ackerman MJ, Balady G, Berger S, Cohen D, et al. Recommendations and considerations related to preparticipation screening for cardiovascular abnormalities in competitive athletes: 2007 update. A scientific statement from the American Heart Association Council on Nutrition, Physical Activity, and Metabolism: endorsed by the American College of Cardiology Foundation. Circulation. 2007;115(12):1643-455.

32. Tajik AJ, Jan MF. The heart of the matter: prime time E/e' prime! JACC Cardiovasc Imaging. 2014;7(8):759-761.

33. Califf RM. The new era of clinical research: using data for multiple purposes. Am Heart J. 2014;168(2):133-134.

34. Maron BJ, Zipes DP. Introduction: Eligibility recommendations for competitive athletes with cardiovascular abnormalities -- general considerations. J Am Coll Cardiol. 2005;45(8):1318-1321.

35. Maron BJ, Pelliccia A. The heart of trained athletes: cardiac remodeling and the risks of sports, including sudden death. Circulation. 2006;114(15):1633-1644.

36. Link MS, Estes NA. Sudden cardiac death in the athlete: bridging the gaps between evidence, policy, and practice. Circulation. 2012;125(20):2511-2516.

37. La Gerche A, Baggish AL, Knuuti J, Prior DL, Sharma S, Heidbuchel $\mathrm{H}$, et al. Cardiac imaging and stress testing asymptomatic athletes to identify those at risk of sudden cardiac death. JACC Cardiovasc Imaging. 2013;6(9): 993-1007.

38. Hall H. Re-thinking the Annual Physical. [updated 2012 February 21; cited 2014 April 14]; Available from: http://www. sciencebasedmedicine.org/re-thinking-the-annual-physical/

39. Moyer VA. Screening for coronary heart disease with electrocardiography: U.S. Preventive Services Task Force recommendation statement. Ann. 2012;157(7):512-518.

40. Chou R, Arora B, Dana T, Fu R, Walker M, Humphrey L. Screening Asymptomatic Adults for Coronary Heart Disease With Resting or Exercise Electrocardiography: Systematic Review to Update the 2004 U.S. Preventive Services Task Force Recommendation. Rockville: Agency for Healthcare Research and Quality (US) [updated 2011 Sep 1; cited 2014 Oct 9]; Available from: http://www.ncbi.nlm.nih.gov/ books/NBK63673/

41. Drezner JA, Fischbach P, Froelicher V, Marek J, Pelliccia A, Prutkin JM, et al. Normal electrocardiographic findings: recognising physiological adaptations in athletes. Br J Sports Med. 2013;47(3):125-136.

42. Anderson JB, Grenier M, Edwards NM, Madsen NL, Czosek RJ, Spar 
DS, et al. Usefulness of combined history, physical examination, electrocardiogram, and limited echocardiogram in screening adolescent athletes for risk for sudden cardiac death. Am J Cardiol. 2014;114(11):1763-1767.

43. Hill AC, Miyake CY, Grady S, Dubin AM. Accuracy of interpretation of preparticipation screening electrocardiograms. J Pediatr. 2011;159(5):783-788.

44. Rowin EJ, Maron BJ, Appelbaum E, Link MS, Gibson CM, Lesser JR, et al. Significance of false negative electrocardiograms in preparticipation screening of athletes for hypertrophic cardiomyopathy. Am J Cardiol. 2012;110(7):1027-1032.

45. Buckley C. Avoiding the Inevitable Social Silo. [updated 2014 April 30; cited 2015 April 14]; Available from: http://www.aiim.org/ community/blogs/expert/Avoiding-the-Inevitable-Social-Silo

46. Osler SW. The Principals and Practice of Medicine. New York: D. Appleton and Company; 1892.

47. Barabasi AL, Gulbahce N, Loscalzo J. Network medicine: a networkbased approach to human disease. Nat Rev Genet. 2011;12(1):56-68.

48. Lipsitz LA. Understanding health care as a complex system: the foundation for unintended consequences. Jama. 2012; 308(3):243244.

49. Siegel A and Etzkorn I. Simple: Conquering the Crisis of Complexicity. New York: Hachette Book Group; 2013.

50. Two's Company, Three is Complexity. Johnson N, editor. Oxford, England: Oneworld; 2007.

51. Hood L, Flores M. A personal view on systems medicine and the emergence of proactive P4 medicine: predictive, preventive, personalized and participatory. N Biotechnol. 2012;29(6):613-624.

52. Barabasi A-L. Linked: How Everything Is Connected to Everything Else and What It Means for Business, Science, Everyday Life. London: Penguin Books Ltd; 2003.

53. Nagueh SF, Appleton CP, Gillebert TC, Marino PN, Oh JK, Smiseth $\mathrm{OA}$, et al. Recommendations for the evaluation of left ventricular diastolic function by echocardiography. J Am Soc Echocardiogr. 2009;22(2):107-133.

54. Lang RM, Badano LP, Mor-Avi V, Afilalo J, Armstrong A, Ernande $\mathrm{L}$, et al. Recommendations for cardiac chamber quantification by echocardiography in adults: an update from the American Society of Echocardiography and the European Association of Cardiovascular Imaging. J Am Soc Echocardiogr. 2015;28(1):1-39.

55. Cohen J, Stewart I. The Collapse of Chaos: Discovering Simplicity in a Complex World. Penguin Adult; 2000.

56. Artificial General Intelligence. Goertzel B and Pennachin C, editors. Berlin Heidelberg: Springer-Verlag; 2010.

57. brainyquote.com. Leonardo da Vinci Quotes. [updated; cited 2014 Nov 11]; Available from: http://www.brainyquote.com/quotes/quotes/l/ leonardoda107812.html

58. Essentialism: The Disciplined Pursuit of Less. 1st Ed. McKeown G, editor. New York: Random Hours Company; 2014.

59. Spencer KT, Kimura BJ, Korcarz CE, Pellikka PA, Rahko PS, Siegel RJ. Focused cardiac ultrasound: recommendations from the American Society of Echocardiography. J Am Soc Echocardiogr. 2013;26(6):567581.

60. Nishimura RA, Tajik AJ. Evaluation of diastolic filling of left ventricle in health and disease: Doppler is the clinician's Rosetta Stone. J Am Coll Cardiol. 1997;30(1): 8-18.

61. Melduni RM, Suri RM, Seward JB, Bailey KR, Ammash NM, Oh JK, et al. Diastolic dysfunction in patients undergoing cardiac surgery: a pathophysiological mechanism underlying the initiation of new-onset post-operative atrial fibrillation. J Am Coll Cardiol. 2011;58(9):953961.

62. Pina IL, Apstein CS, Balady GJ, Belardinelli R, Chaitman BR, Duscha BD, et al. Exercise and heart failure: A statement from the American Heart Association Committee on exercise, rehabilitation, and prevention. Circulation. 2003;107(8):1210-1225.

63. Patil HR, O'Keefe JH, Lavie CJ, Magalski A, Vogel RA and McCullough PA. Cardiovascular damage resulting from chronic excessive endurance exercise. Mo Med. 2012;109(4):312-321.

64. Seward JB, Casaclang-Verzosa G. Infiltrative cardiovascular diseases: cardiomyopathies that look alike. J Am Coll Cardiol. 2010;55(17):17691779.

65. Kahneman D. Thinking, Fast and Slow. 1st Ed. New York: Farrar, Straus and Giroux; 2011.

66. Lloyd-Jones DM. Cardiovascular risk prediction: basic concepts, current status, and future directions. Circulation. 2010;121(15):17681777.

67. Bossuyt PM, Irwig L,CraigJ, Glasziou P.Comparative accuracy: assessing new tests against existing pathways. BMJ. 2006;332(7549):10891092.

68. Minhas R. Eminence-based guidelines: a quality assessment of the second Joint British Societies' guidelines on the prevention of cardiovascular disease. Int J Clin Pract. 2007;61(7):1137-1144.

69. Wilson PW, D'Agostino RB, Levy D, Belanger AM, Silbershatz H, Kannel WB. Prediction of coronary heart disease using risk factor categories. Circulation. 1998;97(18):1837-1847.

70. Eagle KA, Ginsburg GS, Musunuru K, Aird WC, Balaban RS, Bennett SK, et al. Identifying patients at high risk of a cardiovascular event in the near future: current status and future directions: report of a national heart, lung, and blood institute working group. Circulation. 2010;121(12):1447-1454.

71. Cheitlin MD, Armstrong WF, Aurigemma GP, Beller GA, Bierman FZ, Davis JL, et al. ACC/AHA/ASE 2003 Guideline Update for the Clinical Application of Echocardiography: summary article: A report of the American College of Cardiology/American Heart Association Task Force on Practice Guidelines (ACC/AHA/ASE Committee to Update the 1997 Guidelines for the Clinical Application of Echocardiography). J Am Soc Echocardiogr. 2003;108(9): 1146-1162.

72. Davenport C, Cheng EY, Kwok YT, Lai AH, Wakabayashi T, Hyde C, et al. Assessing the diagnostic test accuracy of natriuretic peptides and ECG in the diagnosis of left ventricular systolic dysfunction: a systematic review and meta-analysis. Br J Gen Pract. 2006;56(522):48-56.

73.Wang TJ. Assessing the Role of Circulating, Genetic, and Imaging Biomarkers in Cardiovascular Risk Prediction. . 2011; 123(5): 551565. doi: 10.1161/CIRCULATIONAHA.109.912568.

74. Ahmad T, Fiuzat M, Pencina MJ, Geller NL, Zannad F, Cleland JG, et al. Charting a roadmap for heart failure biomarker studies. JACC Heart Fail. 2014;2(5):477-488.

75. Greenland P, Alpert JS, Beller GA, Emelia JB, Matthew JB, Elyse F, et al. 2010 ACCF/AHA Guideline for Assessment of Cardiovascular Risk in Asymptomatic Adults: Executive Summary. A Report of the American 
College of Cardiology Foundation/American Heart Association Task Force on Practice Guidelines. Circulation. 2010; 122(25):2748-2764.

76. Elliott PM, Anastasakis A, Borger MA, Borggrefe M, Cecchi F, Charron, et al. 2014 ESC Guidelines on diagnosis and management of hypertrophic cardiomyopathy: the Task Force for the Diagnosis and Management of Hypertrophic Cardiomyopathy of the European Society of Cardiology (ESC). Eur Heart J. 2014;35(39): 2733-2779.

77. Brooks MA, Tarini BA. Genetic testing and youth sports. JAMA. 2011; 305(10):1033-1034

78. Lim LS, Haq N, Mahmood S, Hoeksema L. Atherosclerotic cardiovascular disease screening in adults: College Of Preventive Medicine position statement on preventive practice. Am J Prev Med. 2011;40(3):021.

79. Sebastian-Leon P, Vidal E, Minguez P, Conesa A, Tarazona S, Amadoz A, et al. Understanding disease mechanisms with models of signaling pathway activities. BMC. 2014;8(1):121.

80. Loscalzo J, Kohane I and Barabasi AL. Human disease classification in the postgenomic era: a complex systems approach to human pathobiology. Mol Syst Biol. 2007;3124.

81. Wyman RA, Chiu RY, Rahko PS. The 5-minute screening echocardiogram for athletes. J Am Soc Echocardiogr. 2008;21(7):786-788.

82. Bishop MA, Trout JD. 50 Years of Successful Predictive Modeling Should be Enough: Lessons for Philosophy of Science. Philosophy of Science. 2002; S197-S208.

83. Platz E and Solomon SD. Point-of-care echocardiography in the accountable care organization era. Circ. 2012; 5(5):676-682.

84. Jessup M, Abraham WT, Casey DE, Feldman AM, Francis GS, Ganiats TG, et al. 2009 focused update: ACCF/AHA Guidelines for the Diagnosis and of Heart Failure in Adults: a report of the American College of Cardiology Foundation/American Heart Association Task Force on Practice Guidelines: developed in collaboration with the International Society for Heart and Lung Transplantation. Circulation. 2009;119(14):1977-2016.

85. Rohde LE, Palombini DV, Polanczyk CA, Goldraich LA, Clausell N. A hemodynamically oriented -based strategy in the treatment of congestive heart failure. J Card Fail. 2007;13(8):618-625.

86. Seward JB. Physiological aging: window of opportunity. JACC Cardiovasc Imaging. 2011;4(3):243-245.

87. Sengupta PP and Narula J. Cardiac strain as a universal biomarker: interpreting the sounds of uneasy heart muscle cells. JACC Cardiovasc Imaging. 2014;7(5):534-536.

88. Vinereanu D, Florescu N, Sculthorpe N, Tweddel AC, Stephens MR, Fraser AG. Differentiation between pathologic and physiologic left ventricular hypertrophy by tissue doppler assessment of long-axis function in patients with hypertrophic cardiomyopathy or systemic hypertension and in athletes. American Journal of Cardiology. 2001; 88(1):53-58.

89. Popovic D, Ostojic MC, Petrovic M, Vujisic-Tesic B, Popovic B, Nedeljkovic I, et al. Assessment of the left ventricular chamber stiffness in athletes. Echocardiography. 2011;28(3):276-287.

90. Redfield MM, Jacobsen SJ, Burnett JC Jr. Mahoney DW, Bailey KR, Rodeheffer RJ. Burden of systolic and diastolic ventricular dysfunction in the community: appreciating the scope of the heart failure epidemic. JAMA. 2003;289(2):194-202

91. Mor-Avi V, Lang RM, Badano LP, Marek B, Nuno MC, Genevieve D, et al. Current and evolving echocardiographic techniques for the quantitative evaluation of cardiac mechanics: ASE/EAE consensus statement on methodology and indications endorsed by the Japanese Society of Echocardiography. Eur J Echocardiogr. 2011;12(3):167205.

92. Marelli AJ, Mackie AS, Ionescu-Ittu R, Rahme E, Pilote L. Congenital heart disease in the general population: changing prevalence and age distribution. Circulation. 2007;115(2): 163-172.

93. Pearson TA, Blair SN, Daniels SR, Eckel RH, Fair JM, Fortmann SP, et al. AHA Guidelines for Primary Prevention of Cardiovascular Disease and Stroke: 2002 Update: Consensus Panel Guide to Comprehensive Risk Reduction for Adult Patients Without Coronary or Other Atherosclerotic Vascular Diseases. American Heart Association Science Advisory and Coordinating Committee. Circulation. 2002;106(3):388391.

94. Menon SC, Eidem BW, Dearani JA, Ommen SR, Ackerman MJ, Miller D. Diastolic dysfunction and its histopathological correlation in obstructive hypertrophic cardiomyopathy in children and adolescents. J Am Soc Echocardiogr. 2009;22(12):1327-1334.

95. Nagueh SF, Bachinski LL, Meyer D, Hill R, Zoghbi WA, Tam JW, et al. Tissue Doppler imaging consistently detects myocardial abnormalities in patients with hypertrophic cardiomyopathy and provides a novel means for an early diagnosis before and independently of hypertrophy. Circulation. 2001;104(2):128-130

96. Wood MJ, Picard MH. Utility of echocardiography in the evaluation of individuals with cardiomyopathy. Heart. 2004;90(6):707-712.

97. Gabrielli L, Enriquez A, Cordova S, Yanez F, Godoy I and Corbalan R. Assessment of left atrial function in hypertrophic cardiomyopathy and athlete's heart: a left atrial myocardial deformation study. Echocardiography. 2012;29(8):943-949.

98. Maron BJ, Spirito P, Green KJ, Wesley YE, Bonow RO, Arce J. Noninvasive assessment of left ventricular diastolic function by pulsed Doppler echocardiography in patients with hypertrophic cardiomyopathy. J Am Coll Cardiol. 1987;10(4):733-742.

99. D’Andrea A, D’Andrea L, Caso P, Scherillo M, Zeppilli P, Calabro R. The usefulness of Doppler myocardial in the study of the athlete's heart and in the differential diagnosis between physiological and pathological ventricular hypertrophy. Echocardiography. 2006;23(2):149-157.

100. D’Ascenzi F, Cameli M, Zaca V, Lisi M, Santoro A, Causarano A, et al. Supernormal diastolic function and role of left atrial myocardial deformation analysis by 2D speckle tracking echocardiography in elite soccer players. Echocardiography. 2011;28(3):320-326.

101. Pelliccia A, Maron BJ, Di Paolo FM, Biffi A, Quattrini FM, Pisicchio C, et al. Prevalence and clinical significance of left atrial remodeling in competitive athletes. J Am Coll Cardiol. 2005;46(4):690-696.

102. Claessens PJ, Claessens CW, Claessens MM, Claessens MC, Claessens JE. Supernormal left ventricular diastolic function in triathletes. Tex Heart Inst J. 2001; 28(2): 102-110.

103. Lewis JF, Spirito P, Pelliccia A, Maron BJ. Usefulness of Doppler echocardiographic assessment of diastolic filling in distinguishing "athlete's heart" from hypertrophic cardiomyopathy. British Heart Journal. 1992;68(3):296-300.

104. Pagourelias ED, Efthimiadis GK, Kouidi E, Zorou P, Giannoglou G, Deligiannis A, et al. Efficacy of various "classic" echocardiographic and laboratory indices in distinguishing the "gray zone" between athlete's heart and hypertrophic cardiomyopathy: a pilot study. Echocardiography. 2013;30(2):131-139.

105. Pellikka PA. Predicting outcome in asymptomatic aortic stenosis: should we measure the severity of obstruction or its physiological 
consequences? Eur Heart J. 2010;31(18):2191-2193.

106. Kuchynka P, Palecek T, Vilikus Z, Havranek S, Taborska K, Louch $\mathrm{WE}$, et al. Cardiac structural and functional changes in competitive amateur cyclists. Echocardiography. 2010;27(1):11-16.

107. Miyoshi H, Oishi Y, Mizuguchi Y, Iuchi A, Nagase N, Ara N, Oki T, et al. Effect of an increase in left ventricular pressure overload on left atrial-left ventricular coupling in patients with hypertension: a two-dimensional speckle tracking echocardiographic study. Echocardiography. 2013;30(6):658-666.

108. Lam CS, Roger VL, Rodeheffer RJ, Rodeheffer RJ, Bursi F, Borlaug BA, et al. Cardiac structure and ventricular-vascular function in persons with heart failure and preserved ejection fraction from Olmsted County, Minnesota. Circulation. 2007;115(15):1982-1990.

109. Quinones MA. Role of Echocardiography in Predicting Onset of Heart Failure in Patients With Stable Coronary Artery DiseaseIs the Whole Greater Than the Sum of its Parts? JACC: Cardiovascular Imaging. 2009;2(1):21-23.

110. Nihoyannopoulos P, Dawson D. Restrictive cardiomyopathies. Eur ] Echocardiogr. 2009;10(8): iii23-iii33.

111. Aneq MA, Engvall J, Brudin L, Nylander E. Evaluation of right and left ventricular function using speckle tracking echocardiography in patients with arrhythmogenic right ventricular cardiomyopathy and their first degree relatives. Cardiovasc Ultrasound. 2012;10(37):1476-7120.

112. Skouri HN, Dec GW, Friedrich MG and Cooper LT. Noninvasive imaging in myocarditis. J Am Coll Cardiol. 2006; 48(10):2085-2093.

113. Green GA, Uryasz FD, Petr TA, Bray CD. NCAA study of substance use and abuse habits of college student-athletes. Clin J Sport Med. 2001;11(1):51-56.

114. Deligiannis A, Bjornstad H, Carre F, Heidbüchel H, Kouid E, Panhuyzen-Goedkoop NM, et al. ESC study group of sports cardiology position paper on adverse cardiovascular effects of doping in athletes. Eur J Cardiovasc Prev Rehabil. 2006;13(5):687694.

115. Galderisi M, Caso P, Severino S, Petrocelli A, De Simone L, Izzo A et al. Myocardial diastolic impairment caused by left ventricular hypertrophy involves basal septum more than other walls: analysis by pulsed Doppler tissue imaging. J Hypertens. 1999;17(5):685-693.

116. Takamura T, Onishi K, Sugimoto T, Kurita T, Fujimoto N, Dohi K, et al. Patients with a hypertensive response to exercise have impaired left ventricular diastolic function. Hypertens Res. 2008;31(2):257263.

117. Silvilairat S, Cetta F, Biliciler-Denktas G, Ammash NM, Cabalka AK, Hagler DJ, et al. Abdominal aortic pulsed wave Doppler patterns reliably reflect clinical severity in patients with coarctation of the aorta. Congenit Heart Dis. 2008;3(6):422-430.

118. Becker AE, Becker MJ, Edwards JE. Anomalies associated with coarctation of aorta: particular reference to infancy. Circulation. 1970;41(6):1067-1075.

119. Burke AP, Farb A, Virmani R, Goodin J, Smialek JE. Sports-related and non-sports-related sudden cardiac death in young adults. Am Heart J. 1991;121(2 Pt 1): 568-75.

120. Schroeder S, Achenbach S, Bengel F, Burgstahler C, Cademartiri $\mathrm{F}$, de Feyter $\mathrm{P}$, et al. Cardiac computed tomography: indications, applications, limitations, and training requirements: report of a
Writing Group deployed by the Working Group Nuclear Cardiology and Cardiac CT of the European Society of Cardiology and the European Council of Nuclear Cardiology. Eur Heart J. 2008; 29(4): 531-556.

121. Seward JB, Tajik AJ, Edwards WD and Hagler DJ. Two-dimensional Echocardiographic Atlas. New York: Springer-Verlag; 1987.

122. Gersony WM. Management of anomalous coronary artery from the contralateral coronary sinus. J Am Coll Cardiol. 2007; 50(21): 20832084. Epub 2007 Nov 5.

123. Pelliccia A, Spataro A, Maron BJ. Prospective echocardiographic screening for coronary artery anomalies in 1,360 elite competitive athletes. Am J Cardiol. 1993;72(12):978-979.

124. Davies RR, Gallo A, Coady MA, Tellides G, Botta DM, Burke B, et al. Novel measurement of relative aortic size predicts rupture of thoracic aortic aneurysms. Ann Thorac Surg. 2006;81(1):169-177.

125. Yetman AT and Graham T. The dilated aorta in patients with congenital cardiac defects. J Am Coll Cardiol. 2009; 53(6):461-467.

126. Marsalese DL, Moodie DS, Lytle BW, Cosgrove DM, Ratliff NB, Goormastic M, et al. Cystic Medial Necrosis of the Aorta in Patients Without Marfan's Syndrome: Surgical Outcome and LongTerm Follow-Up. J Am Coll Cardiol. 1990;16(1):1668-1673.

127. Meier JH, Seward JB, Miller FA Jr, Oh JK and Enriquez-Sarano M. Aneurysms in the left ventricular outflow tract: clinical presentation, causes, and echocardiographic features. J Am Soc Echocardiogr. 1998;11(7):729-745

128. Losenno KL, Goodman RL, Chu MWA. Bicuspid Aortic Valve Disease and Ascending Aortic Aneurysms: Gaps in Knowledge. Cardiology Research and Practice. 2012(2012):145202.

129. Braverman AC. Aortic involvement in patients with a bicuspid aortic valve. Heart. 2011;97(6) 506-513.

130. Siu SC and Silversides CK. Bicuspid Aortic Valve Disease. Journal of the American College of Cardiology. 2010; 55(25): 2789-2800.

131. Seward JB, Tajik AJ, Hagler DJ, Edwards WD. Internal cardiac crux: two-dimensional echocardiography of normal and congenitally abnormal hearts. Ultrasound Med Biol. 1984;10(6):735-745.

132. Yared K, Noseworthy P, Weyman AE, McCabe E, Picard MH, Baggish AL. Pulmonary artery acceleration time provides an accurate estimate of systolic pulmonary arterial pressure during transthoracic echocardiography. J Am Soc Echocardiogr. 2011;24(6):687-692.

133. Dabestani A, Mahan G, Gardin JM, Takenaka K, Burn C, Allfie A, et al. Evaluation of pulmonary artery pressure and resistance by pulsed Doppler echocardiography. Am J Cardiol. 1987;59(6):662-668.

134. Milan A, Magnino C and Veglio F. Echocardiographic indexes for the non-invasive evaluation of pulmonary hemodynamics. J Am Soc Echocardiogr. 2010;23(3):225-239.

135. Marijon E, Tafflet M, Celermajer DS, Florence Dumas, Marie-Cec ile Perier, Hazrije mustafic, et al. Sports-related sudden death in the general population. Circulation. ;124(6): 672-681.

136. Desai CS, Colangelo LA, Liu K, Jacobs DR Jr, Cook NL, Lloyd-Jones DM, et al. Prevalence, prospective risk markers, and prognosis associated with the presence of left ventricular diastolic dysfunction in young adults: the coronary artery risk development in young adults study. Am J Epidemiol. 2013;177(1):20-32.

137. Berger JS, Jordan CO, Lloyd-Jones D, Blumenthal RS. Screening for cardiovascular risk in asymptomatic patients. J Am Coll Cardiol. 2010;55(12):1169-1177. 
138. Maron BJ, Araujo CG, Thompson PD, Fletcher GF, de Luna AB, Fleg $\mathrm{JL}$, et al. Recommendations for preparticipation screening and the assessment of cardiovascular disease in masters athletes: an advisory for healthcare professionals from the working groups of the World Heart Federation, the International Federation of Sports Medicine, and the American Heart Association Committee on Exercise, Cardiac Rehabilitation, and Prevention. Circulation. 2001;103(2):327-334.

139. Hoffmann S, Jensen JS, Iversen AZ, Sogaard P, Galatius S, Olsen NT, et al. Tissue Doppler echocardiography improves the diagnosis of coronary artery stenosis in stable angina pectoris. Eur Heart J Cardiovasc Imaging. 2012;13(9):724-729.

140. Ohara T and Little WC. Evolving focus on diastolic dysfunction in patients with coronary artery disease. Curr Opin Cardiol. 2010; 25(6): 613-621.

141. Alsaileek AA, Osranek M, Fatema K, McCully RB, Tsang TS, Seward JB. Predictive value of normal left atrial volume in stress echocardiography. J Am Coll Cardiol. 2006;47(5):1024-1028.

142. McClell RL, Chung H, Detrano R, Post W, Kronmal RA. Distribution of coronary artery calcium by race, gender, and age: results from the Multi-Ethnic Study of Atherosclerosis (MESA). Circulation. 2006;113(1):30-37.

143. Nishimura RA, Otto CM, Bonow RO, Carabello BA, Erwin JP 3rd, Guyton RA, et al. 2014 AHA/ACC Guideline for the Management of Patients With Valvular Heart Disease: executive summary: a report of the American College of Cardiology/American Heart Association Task Force on Practice Guidelines. Circulation. 2014;129(23):24402492.

144. Rahimtoola SH. Valvular heart disease: a perspective on the asymptomatic patient with severe valvular aortic stenosis. Eur Heart J. 2008;29(14):1783-1790.

145. Otto CM, Burwash IG, Legget ME, Munt BI, Fujioka M, Healy NL, et al Prospective study of asymptomatic valvular aortic stenosis. Clinical, echocardiographic, and exercise predictors of outcome. Circulation. 1997;95(9):2262-2270

146. Pibarot P, Dumesnil JG. Improving assessment of aortic stenosis. J Am Coll Cardiol. 2012;60(3):169-180

147. Oh JK, Seward JB and Tajik AJ. The Echo Manual. 3rd Ed. DeStefano F, Seto J, Dougherty B, Rivera B, Panetta A, Smock D and e. Philadelphia: Lippincott Williams \& Wilkins; 2006.

148. Miller FA, Jr., Seward JB, Gersh BJ, Tajik AJ, Mucha P Jr. Twodimensional echocardiographic findings in cardiac trauma. Am J Cardiol. 1982; 50(5): 1022-1027.

149. Shahid MS, Hatle L, Mansour H, Mimish L. Echocardiographic and Doppler study of patients with heatstroke and heat exhaustion. Int J Card Imaging. 1999;15(4):279-285.

150. Sudden Arrhythmia Death Syndromes Foundation. Screening to Prevent Sudden Death. [updated 2009 Nov; cited 2015 April 18]; Available from: http://www.sads.org/advocacy/actions---alerts/ screening-to-prevent-sudden-death\#.VTJIkiFVikp

151. Haugaa KH, Johnson JN, Bos JM, Phillips BL, Eidem BW, Ackerman MJ. Subclinical cardiomyopathy and long QT syndrome: an echocardiographic observation. Congenit Heart Dis. 2013;8(4):352359.

152. Priori SG, Wilde AA, Horie M, Cho Y, Behr ER, Berul C, et al. HRS/ EHRA/APHRS expert consensus statement on the diagnosis and management of patients with inherited primary arrhythmia syndromes: document endorsed by HRS, EHRA, and APHRS in May 2013 and by ACCF, AHA, PACES, and AEPC in June 2013. Heart Rhythm. 2013; 10(12): 1932-63.

153. Napolitano C, Bloise R, Monteforte N, Priori SG. Sudden cardiac death and genetic ion channelopathies: long QT, Brugada, short QT, catecholaminergic polymorphic ventricular tachycardia, and idiopathic ventricular fibrillation. Circulation. 2012; 125(16): 2027 2034 